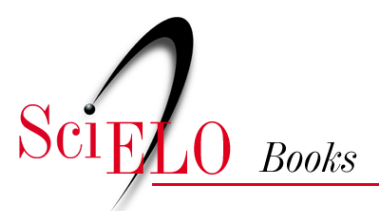

\title{
Dom José Gomes
}

\author{
José Carlos Radin \\ Gentil Corazza
}

\section{SciELO Books / SciELO Livros / SciELO Libros}

RADIN, J.C., and CORAZZA, G. Dom José Gomes. In: Dicionário histórico-social do Oeste catarinense [online]. Chapecó: Editora UFFS, 2018, pp. 50-52. ISBN: 978-85-64905-65-8. https://doi.org/10.7476/9788564905658.0011.

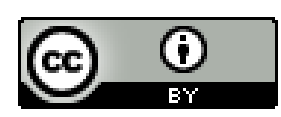

All the contents of this work, except where otherwise noted, is licensed under a Creative Commons Attribution 4.0 International license.

Todo o conteúdo deste trabalho, exceto quando houver ressalva, é publicado sob a licença Creative Commons Atribição 4.0.

Todo el contenido de esta obra, excepto donde se indique lo contrario, está bajo licencia de la licencia $\underline{\text { Creative Commons }}$ Reconocimento 4.0. 


\section{Dom José Gomes}

Dom José Gomes foi bispo das Dioceses de Bagé, entre 1961 e 1968, e de Chapecó, entre 1968 e 1998. Ele nasceu em 25 de março de 1921 no atual município de Erechim e morreu, em Chapecó, aos 81 anos, em 19 de setembro de 2002. Seu avô paterno era espanhol e sua avó, italiana, mas seus pais nasceram no Brasil. José era o quinto dos nove filhos de Antônio Gomes e Maria Maggioni. Seu pai era madeireiro, proprietário de uma serraria e morreu de mal súbito, em 1932, aos 45 anos. José fez o curso básico em sua cidade natal e, depois, ingressou no Seminário São José de Santa Maria, onde frequentou o nível científico. Depois seguiu com os cursos de Filosofia e Teologia no Colégio Cristo Rei dos padres jesuítas, em São Leopoldo. Recebeu as ordens menores na cidade de Selbach e foi ordenado padre em 1947, aos 28 anos de idade. Começou suas atividades como vigário cooperador na paróquia de Espumoso, em 1948, onde ficou por dois anos, até 1949. Em 1950, é chamado para trabalhar na Catedral de Santa Maria. Entre 1951 e 1961, desempenhou suas atividades na catedral de Passo Fundo, onde foi membro da Academia de Letras e se envolveu na promoção do ensino superior, ajudando a criar diversas faculdades, dentre as quais a Faculdade de Filosofia, onde também lecionou. Essas faculdades formariam, depois, o embrião da atual Universidade de Passo Fundo.

Em 25 de março de 1961, aos 40 anos, José Gomes é nomeado Bispo da Diocese de Bagé. Como já havia feito em outros lugares onde havia trabalhado, ele costumava envolver-se com as questões sociais, sempre se colocando ao lado dos mais pobres e necessitados. Em Bagé não foi diferente. A questão mais aguda daquele momento era a da reforma agrária. Os trabalhadores tentavam organizar-se através da criação do Sindicado dos Trabalhadores Rurais, organização não aceita pelos proprietários de terras. A tensão e o conflito entre os sem-terra e os fazendeiros intensificaram-se. Dom José, desde o início, tomou posição firme em defesa do direito dos trabalhadores em formar seu sindicato. Mas sua luta foi bruscamente interrompida. Inexplicavelmente, de uma hora para a outra, em 1968, Dom José foi 
transferido para a Diocese de Chapecó. Foi uma transferência difícil de explicar. Causou estranheza e consternação. Houve muitas manifestações e protestos.

Em Chapecó, desenvolveu ampla atuação por meio das Pastorais Sociais, como a Pastoral da Saúde, a Operária, a da Juventude e principalmente a da Comissão Pastoral da Terra (CPT), da qual também foi presidente nacional. Desde o início, Dom José deu continuidade a suas atividades de defesa e apoio aos movimentos sociais. As frentes eram muitas. Movimento dos Trabalhadores Rurais Sem-Terra (MST), Movimento de Mulheres Agricultoras (MMA), hoje denominado Movimento de Mulheres Camponesas (MMC) e o Movimento dos Atingidos por Barragens (MAB). Assumiu, também, a defesa dos interesses indígenas, atuando através do Conselho Indigenista Missionário (CIMI), que ajudou a criar e do qual foi seu primeiro presidente.

No seu intenso trabalho social, mostrava-se sempre preocupado com a violência que os trabalhadores sem-terra pudessem sofrer e recomendava muita cautela nas ocupações de terra, temendo a reação dos proprietários e seus métodos violentos. Em nenhum momento, porém, deixou de reconhecer e de apoiar o direito dos trabalhadores de lutar pelos seus interesses. "Defendemos o direito que o povo tem de lutar pela terra". "Eu era contra a invasão, mas os trabalhadores são autônomos", não me cabe dar ordens, "eles não pediram nem a minha bênção", afirmou ele, brincando, antes de uma ocupação. "O método da invasão é novo, mas é deles”. Julgava ser uma forma legítima de pressão para que as autoridades reconhecessem o direito dos trabalhadores a possuírem sua terra para trabalhar.

Lutou sempre por uma igreja menos hierarquizada, menos apegada às tradições seculares e mais aberta para as causas populares. Nas décadas de 1970 e 80, os conflitos foram mais intensos, mas Dom José nunca esmoreceu, apesar das perseguições e ameaças que sofreu. Ele se manteve sempre firme na defesa dos direitos dos pequenos e excluídos, quer fossem índios, trabalhadores sem-terra e pequenos agricultores. Dom José sempre defendeu a todos e, por isso, o povo o referenciava como o "porta-voz da justiça". Ele sofria muitas pressões das elites locais. Em 1968, em meio a grandes conflitos, o Governo do Estado 
solicitou sua intermediação. Dom José nunca se negou a colaborar, mas deixou claro para as autoridades que "é com o MST que vocês têm que negociar" e não comigo. Ele tinha uma aguda lucidez política e habilidade para incentivar as pessoas a lutarem por seus direitos.

Sua ação e suas lutas devem ser entendidas no contexto das grandes transformações pelas quais passou o Oeste catarinense, como foi o avanço agressivo do capitalismo no campo, o novo modelo de produção voltado para a exportação, o surgimento das grandes agroindústrias, a concentração da terra, o êxodo rural, os problemas decorrentes da urbanização e o processo de marginalização dos pequenos agricultores. Sem Dom José, a história do Oeste catarinense seria outra. Ele foi um "arquiteto de consciências". As elites locais se opunham à atuação social de Dom José e promoviam campanhas difamatórias e ataques violentos; a opinião pública oficial, a prefeitura municipal e as forças econômicas e políticas, através dos meios de comunicação, rádios, jornais e televisão, responsabilizavam o bispo pelos conflitos.

Dom José Gomes trabalhou durante mais de trinta anos na Diocese de Chapecó. Entretanto, sua liderança e suas ações em defesa dos direitos dos sem direitos fizeram-se sentir em todo o Brasil. Em 1998, aposentou-se de suas funções oficiais, permanecendo como bispo emérito, até sua morte, em 2002. Seu corpo está enterrado na própria catedral de Chapecó.

\section{REFERÊNCIAS}

CEOM. Sermões do Bispo Dom José Gomes. Chapecó: Argos, 2012. GOBBO, André. Dom José Gomes Escudo dos Oprimidos. São Paulo: Paulinas, 2002.

UCZAI, Pedro. Dom José Gomes: mestre e aprendiz do povo. Chapecó: Argos, 2002. 